\title{
Radioimmunoassay of AGTH in Human Plasma
}

\author{
Shigeyoshi YUJI and Toshiro NAKAJIMA \\ Department of Internal Medicine, Kyushu Dental College, Kitakyushu, Japan \\ (Director : Professor Nobuhiko Okabe, M.D.)
}

\author{
Akira WATANABE \\ Second Department of Internal Medicine, Faculty of Medicine Kyushu University, \\ Fukuoka, Japan (Director : Professor Shibanosuke Katsuki, M.D.)
}

Adrenocorticotropic hormone is a relatively poor antigen, and difficulties in obtaining antisera which are sufficiently sensitive for radioimmunoassay of plasma ACTH have been reported by several workers.

In the present study, guinea pigs were immunized by subcutaneous injections at biweekly intervals with $20 \mathrm{U}$ of commercial porcine ACTH emulsified in complete Freund's adjuvant or acetylated wax $\mathrm{D}(\mathrm{AD})$ which contained less competing antigens than bacillary bodies of Mycobacteria. Antisera obtained by 8 injections were not sensitive for the measurement of plasma ACTH, though animals injected with acetylated wax D induced slightly increased production of the antibody.

Guinea pigs in another immunization schedule were given $30 \mathrm{U}$ of commercial porcine ACTH mixed with metyrapone and complete Freund's adjuvant by monthly subcutaneous injections. The antiserum used for assay was obtained from one guinea pig after 14 months.

Highly purified porcine ACTH supplied by Mann Laboratories was iodinated by the chloramine $\mathrm{T}$ method and purified with QUSO G32. Specific activities ranged from 300 to $400 \mathrm{mc} / \mathrm{mg}$. The reference standard used was highly purified human ACTH supplied by Dr. Lee.

The assay was performed by a modified method of Berson \& Yalow. ${ }^{125}$ I-porcine ACTH of $1 \mu \mu \mathrm{g}$, antiserum at a final dilution of $1: 50,000$ and unknown plasma of $0.2 \mathrm{ml}$ were added to a final incubation volume of $1.0 \mathrm{ml}$. The mixtures were incubated at $4^{\circ} \mathrm{C}$ for 7 days. Talc was used for separation of antibody bound and free labeled hormone.

A minimum of $16 \mu \mu \mathrm{g} / \mathrm{ml}$ of ACTH was detected in the assay. Therefore, $80 \mu \mu \mathrm{g}$ $\mathrm{ACTH} / \mathrm{ml}$ of whole plasma was measurable in plasmas assayed at $1: 5$ dilutions. Plasma concentrations in normal subjects ranged from less than 80 to $160 \mu \mu \mathrm{g} / \mathrm{ml}$ at 9 a.m.. Increased concentrations were observed in patients with Addison's disease and Cushing's syndrome associated with bilateral adrenal hyperplasia. Plasma ACTH levels were undetectable in normal subjects pretreated with dexamethasone and patients with Cushing's syndrome associated with adrenal adenoma. The administration of metyrapone in patients with Cushing's syndrome produced an increase in plasma ACTH concentration in those with bilateral adrenal hyperplasia, whereas no significant change in those with adrenal adenoma.

(See pp. 110 114) 


\title{
ACTH の Radioimmunoassay に関する研究
}

\author{
九州蒾科大学内科学教室（主任 岡部信彦教授） \\ 湯 地 重 壬, 中 島 敏 郎 \\ 九州大学医学部第二内科学教室（主任 勝木司馬之助教授）
}

渡辺斌

（昭和45年12月28日受付）

豚 ACTH を metyrapone と complete Freund's adjuvant そ加光てモルモットに1月1回の免疫 を行ない，14ケ月目に得られた抗血清を用い，血漿を $1: 5$ 亿希釈して assay を行なつた. 正常人の血 漿 ACTH 值は80以下〜 $160 \mu \mu \mathrm{g} / \mathrm{ml}$, 副腎腺腫によるCushing 症候群では検出不能で, 過形成による ものおよび Addison 病では高值を示した. metyrapone 投与により Cushing 症候群の腺嗹例では反 応がみられなかつたが，過形成例では血中 ACTH は上昇し，両者の鑑別に有用と考えられた。

\section{緒呾}

人の血中 ACTH を radioimmunoassay によつて測定するに当つては, 他の peptide hormone にくら べて ACTH の血中濃度が低いとと, ACTH に対する抗体産生が困難であるてと, また抗体が多様性を示 すととなどが問題点とされている1)2 . 我々はてれらの点を検討し，あわせて臨床例の血中 ACTH 值につ いて若干の知見を得たので報告する。

\section{方法}

ACTH 抗血清を作製するためにモルモットを次のでとく2 群に分けて免疫を行なつた。 1 群は 1 匹あた り市販の Organon NH ACTH plain または ACTH-Z の20単位 $(0.5 \mathrm{ml})$ を等量の complete Freund’s adjuvant と混和し， 2 週間に 1 回，大腿内側に皮下注射し，その 1 週後に心穿刺により採血して抗体産生 の経過を検討した，他の群には結核菌体成分であるロウDの水酸基をアセチル化したもの,すなわち acetylated wax D (AD) を adjuvant として同様の免疫を行なつた ${ }^{3)}$. との AD $10 \mathrm{mg}$ と Durakeol No. 6 $0.4 \mathrm{ml}$ と Arlacel A $0.1 \mathrm{ml}$ を混和したものを 1 匹あたりに使用した.

上記の方法で得られた抗血清の他にさらに著者の 1 人湯地が Los Angeles Veterans Administration Center で作製した抗血清を血中 ACTH の測定に使用した。これはモルモットに1匹あたり，Duracton 豚 ACTH 30単位と metyrapone 75mg を等量の complete Freund's adjuvant そ混和して, 1 月に1回, 大腿内側に皮下注射し，14回目の免疫後10日目に採血した抗血清VA(1)1-14 である.

標識 ACTH は Iso-Serve の高比放射能の ${ }^{125} \mathrm{I}$ を用いて, Mann Laboratories の highly purified 豚 ACTH を chloramine $\mathrm{T}$ 法で iodination し4), purification は QUSO G32 法によつて行なつた5). 得 られた ${ }^{125} \mathrm{I}$-ACTH の比放射能は 300〜 400 mc/mg であつた。標準 AGTH は Dr. Lee の highly purified 人 ACTH $(25 \mathrm{U} / \mathrm{mg})$ を使用した.

assay は Berson \& Yalow の方法 ${ }^{1}$ に準じて行ない, standard diluent は $2.5 \%$ 人血清アルブミン, $1 \%$ 正常モルモット血墏，0.4\% mercaptoethanol および $375 \mathrm{KIU} / \mathrm{ml}$ の Trasylol を含む 0.05M phosphate buffer（pH 7.5）を用い，標準 ACTH，標識 ACTH および抗血清は全てとれにて希釈した。 incubation 
は siliconize した試験管を使用して全量を $1.0 \mathrm{ml}$ とし， $4{ }^{\circ} \mathrm{C} て ゙ 7$ 日間行なつた。

抗血清の希釈曲線作製に用いた ${ }^{125} \mathrm{I}-\mathrm{ACTH}$ は最終濃度が $4 \mu \mu \mathrm{g} / \mathrm{ml}$ であり, incubation 終了後 $0.2 \mathrm{ml}$ の正常人血漿と $1.5 \mathrm{ml}$ の standard diluent および $50 \mathrm{mg}$ Talc 錠を加えてVortex 振蕰器で振盪して遠 沈し，Talc(F) と上清(B)をそれぞれ automatic well-type scintillation counter にて放射能を測定し， $\mathrm{B} / \mathrm{F}$ を算定した，検体の血漿 AGTH 測定には incubation 溶液は血漿 $0.2 \mathrm{ml}$ を含む $1.0 \mathrm{ml}$ とし， ${ }^{125} \mathrm{I}-$ ACTH の最終浱度を $1 \mu \mu \mathrm{g} / \mathrm{ml}$ とし, 抗血清は $1: 50,000$ の最終希勫度で使用した. 標準 ACTH の incubation 溶液には $0.2 \mathrm{ml}$ の dexamethasone 処理正常人血漿を含ませ, 両者とも incubation 後, $1.5 \mathrm{ml}$ の standard diluent と Talc $50 \mathrm{mg}$ を抗血清希釈曲線の場合と同様に加え，遠沈して B と F を分離した. 血中 ACTH 在测定したのは正常人 5 例および九大第二内科入院患者 8 例と福岡赤十字病院内科入院中の副 腎腺腫による Gushing 症候群の1例である. 尿 17-OHCS は西風らの方法により定量を行なつた ${ }^{6)}$.

\section{結 果}

Fig. 1 は complete Freund's adjuvant を用いて，NH ACTH plain で免疫した 3 匹および AGTH-Z による 1 匹の計 4 匹と，AD adjuvant を用いて NH AGTH plain で免疫した 2 匹およびZによる 1 匹の 計 3 匹の抗体産生の経過を示したものである. 抗血清の $1: 500$ 最終希釈度における抗体の結合度 $\mathrm{B} / \mathrm{T}$ は いずれも最高 $50 \%$ にどまり，十分な抗体価の上昇はどの例にも認められなかつたが，4回の免疫までは AD adjuvant の方が結合度の上昇が高い傾向がうかがわれた。

Fig. 2 は complete Freund's adjuvant を用いた動物番号 2 と AD adjuvant を用いた動物番号 3 のそ れぞれの各 ACTH 注射後の抗血清の希釈曲線の経過を示したものである. 両者とも5回目の免疫以後は

Fig. 1. Production of anti-porcine ACTH antibody by guinea pigs.

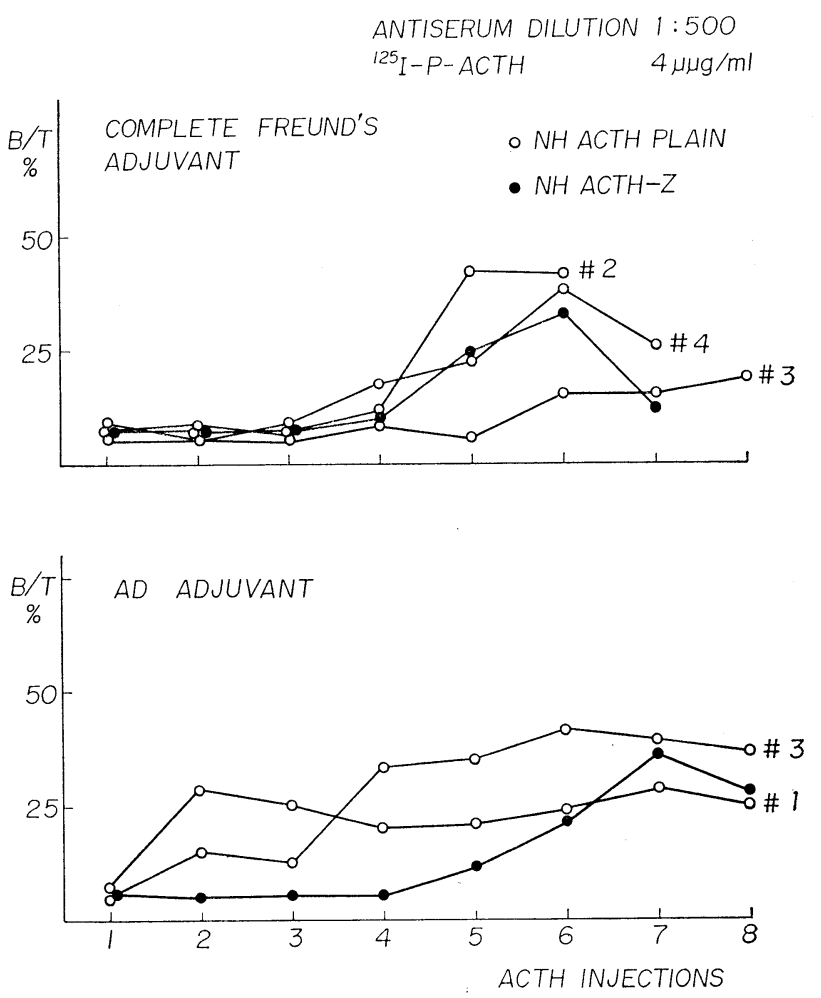

第 47 巻 第 2 号 
Fig. 2. Titration curves of antiserum to porcine ACTH with ${ }^{125} \mathrm{I}$-porcine ACTH $(4 \mu \mu \mathrm{g} / \mathrm{ml})$

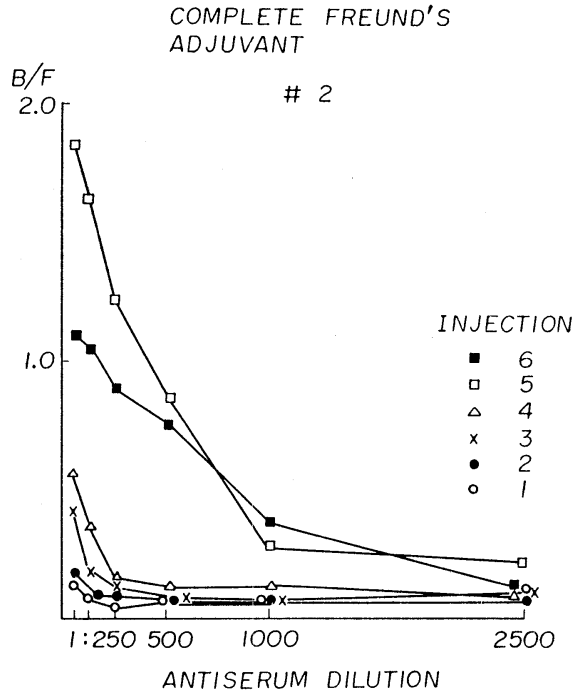

Fig. 3. AGTH standard curve.

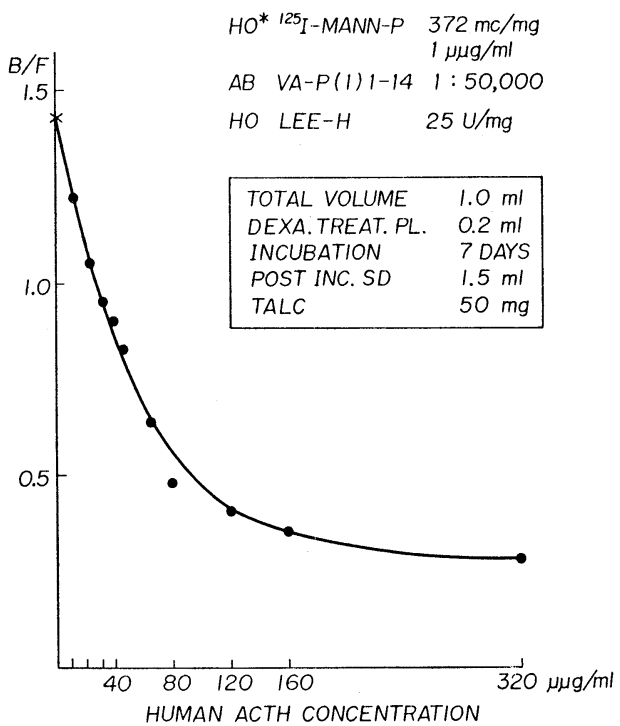

AD ADJUVANT

\# 3

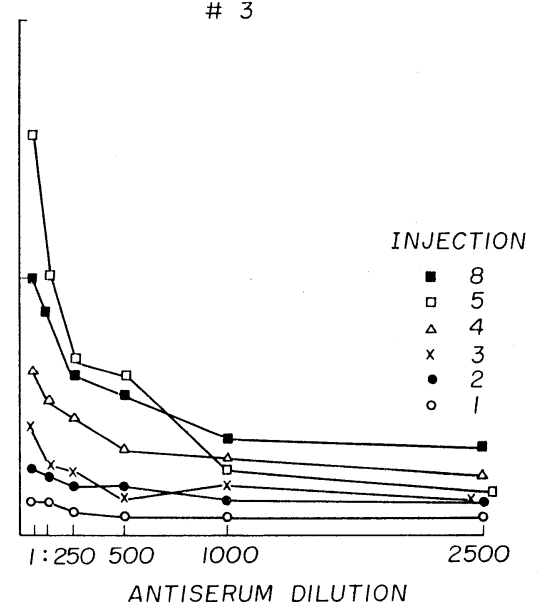

Fig. 4. Plasma ACTH concentrations in normal subjects and patients with Gushing's syndrome and Addison's disease.

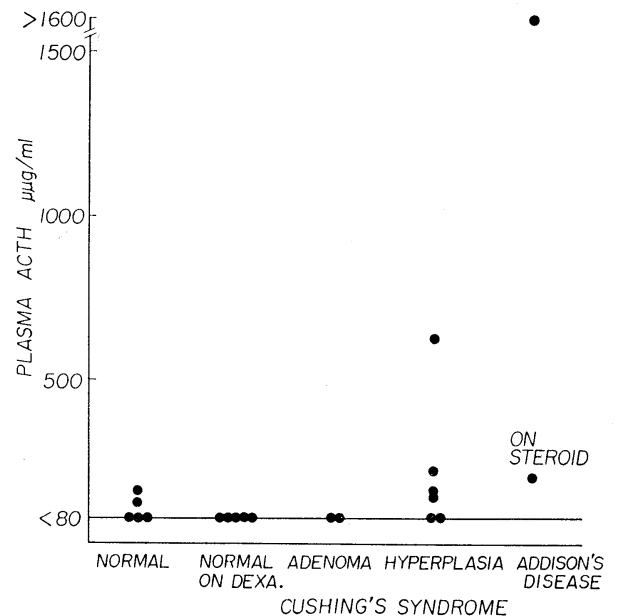

B/F が 1.0〜2.0より下降する曲線が得られたが，B/F が1.0前後を示す 1：125および $1 ： 250$ 最終希釈 度を用いて前述の方法で標準 ACTH ならびに Addison 病患者血獎について assay を行なつたが，いず れも十分な感度を得るに至らなかつた。

VA(1)1-14 を用いて作製した標準曲線を Fig.3 に，血中 AGTH の測定值を Fig. 4 に示した. ての標準 ACTH の感度は $16 \mu \mu \mathrm{g} / \mathrm{ml}$, 血漿では 5 倍希釈を用いているので $80 \mu \mu \mathrm{g} / \mathrm{ml}$ であつた. 正常人 5 例では午 前 9 時の值は80以下 $160 \mu \mu \mathrm{g} / \mathrm{ml}$ であり, dexamethasone $1 \mathrm{mg}$ を午後11時に投与して翌朝 午前 9 時に採 血したものはいずれも $80 \mu \mu \mathrm{g} / \mathrm{ml}$ 以下となつた。副腎腺腫による Cushing 症候群の 2 例は $80 \mu \mu \mathrm{g} / \mathrm{ml}$ 以 
下，過形成による 6 例は 80 以下 $620 \mu \mu \mathrm{g} / \mathrm{ml}$ であつた。過形成例の 6 例ともすでに下垂体の ${ }^{60} \mathrm{Co}$ 照射， 経鼻的定位手術による下垂体高周波凝固術，一側副篮摘出等の治療を受けた患者であつたが，現在なお臨床 症状, 臨查成績が Cushing 症候群の所見を呈するものが4例あり，その血中 ACTH 值はそれぞれ 160, $160,210,620 \mu \mu \mathrm{g} / \mathrm{ml}$ であつた. 2 例は現在 Cushing 症候群の所見は認められない例であり，その值は両 例とも $80 \mu \mu \mathrm{g} / \mathrm{ml}$ 以下であつた. Addison 病の 1 例は $1600 \mu \mu \mathrm{g} / \mathrm{ml}$ 以上の高值を示し, hydrocortisone

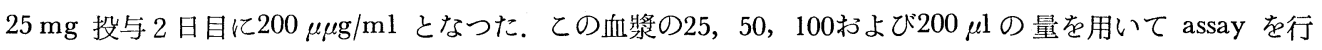
なつて得た值はそれぞれ $1600,2550,1930 \mu \mu \mathrm{g} / \mathrm{m} 1$ と $1600 \mu \mu \mathrm{g} / \mathrm{ml}$ 以上であり, 血漿の希釈度にほぼ一致 した測定値が得られた。

過形成による Cushing 症候群の 1 例と腺腫による 2 例の methyrapone に対する血中 AGTH および尿 17-OHCS の反応をみた成績ぶ Fig. 5 である，metyrapone は 1 日 $3 \mathrm{~g}$ を 4 時間おきに内服させ，血中 ACTH は投与直前の午前 9 時, 投与後の午後 3 時, 午後 9 時, 翌日午前 9 時に測定したが, 過形成例では 尿 17-OHCS，血中 ACTH とも metyrapone に対して增加か認められた。 ての例は経畀的定位手術によ る下垂体高周波凝固術を受けたが，その 2 週後も同様の反応がみられた，腺腫の 2 例では尿 17-OHCS，血 中 ACTH の metyrapone に対する反応は共に認められなかつた。

Fig. 5. Responses of plasma AGTH and urinary 17-OHCS to metyrapone in patients with Cushing's syndrome. Metyrapone(M) 500mg p.o. every $4 \mathrm{hr} \times 6$ from 9 a.m. day 4 .

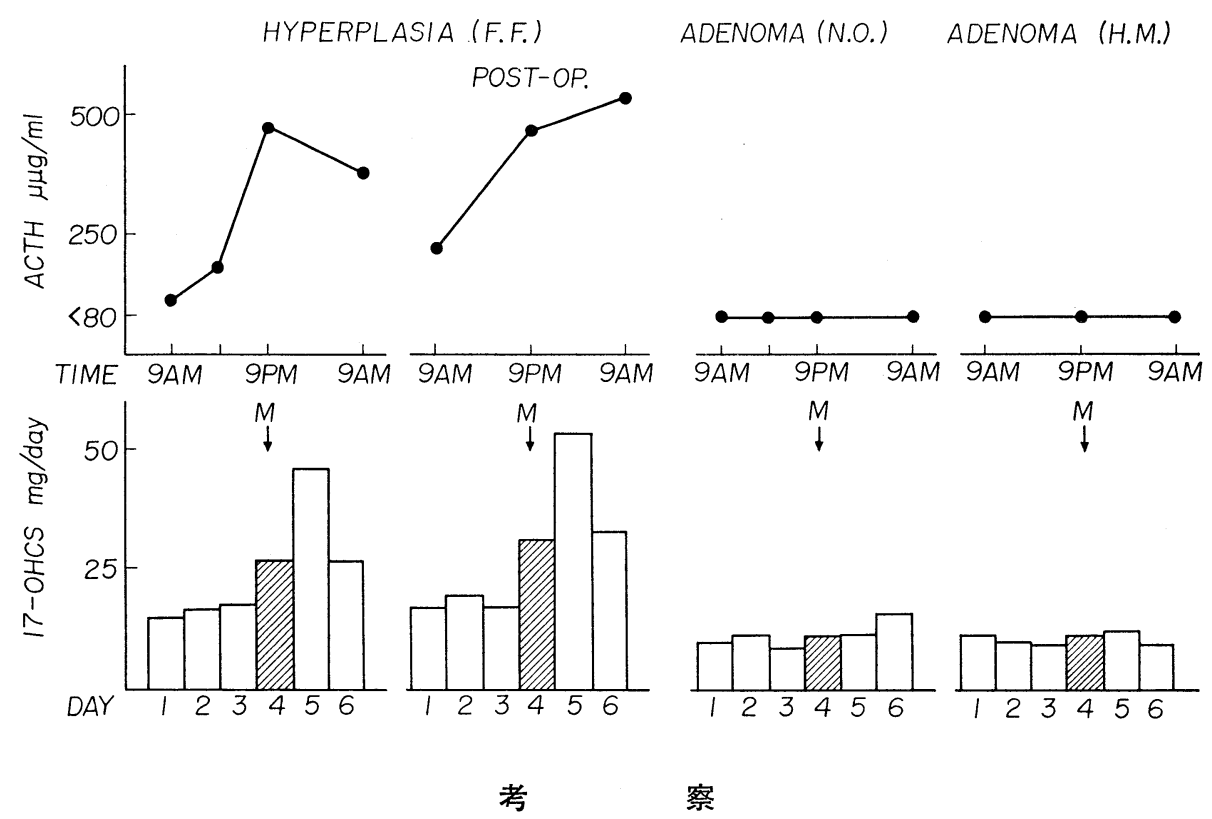

Radioimmnnoassay によつて血中 ACTH を抽出操作なしに直接に測定し得た報告に Berson \& Yalow ${ }^{1)}$ ， Rayyis $ら^{7)}$ ， 過剩の抗体を用いて reverse portion を利用した松倉 ${ }^{8)}$ の論文がある. 血中 AGTH を直接に 測定するためにはその濃度が低いために，少量の標識 AGTH を使用するとと， high affinity を持つた抗 血清を用いるととが必要である ${ }^{1)}$. 標識 AGTH は高比放射能の ${ }^{125} \mathrm{I}$ または ${ }^{131} \mathrm{I}$ を用いて作製することが 出来るが， ${ }^{125} \mathrm{I}-\mathrm{ACTH}$ は ${ }^{131} \mathrm{I}$ にくらべてより微量を利用出来るので有利であり ${ }^{1)}$, 今回の実験でも ${ }^{125} \mathrm{I}-$ ACTH を用いた. 抗体の産生は困難であり, 諸家によつて種々の試みがなされている.

ACTH の分子量は小さく, そのため ACTH を牛アルブミン等の蛋白と coupling させて免疫する方法 ${ }^{7)}$ や，副腎皮質よりの glucocorticoid 合成を阻害する metyrapone (11 $\beta$-hydroxylase inhibitor) とともに 
投与して抗体産生を高める方法 ${ }^{199}$ によつて優れた抗血清が作製されている. complete Freund's adjuvant はその中の結核菌体に含まれる蛋白成分が，免疫を行なう抗原と競合して抗体産生を阻害するてとが考元ら れ ${ }^{3)}, \mathrm{AD}$ adjuvant はての競合する蛋白成分が少ないため, ACTH のように抗原作用の弱い場合は抗体産 生が増強されるととを予期して使用したが，十分な結果を得るととが出来なかつた。一方，metyrapone を 使用し，1月 1 回の免疫で13ケ月以降に assay に使用し得る抗血清を得た. ACTH の抗体産生は使用した 動物の種類と個体差, AGTH 製剤の差，免疫方法さらに免废期間などが関与しているてとがてれらの成績 より推定された.

血漿 ACTH の radioimmunoassay による測定值は bioassay による值とほぼ一致し，正常人の午前 8 〜 9 時の值は $10 \sim 100 \mu \mu \mathrm{g} / \mathrm{ml}$ 程度とされている(1)2)810). その值を直接測定するだけの感度の得られない場

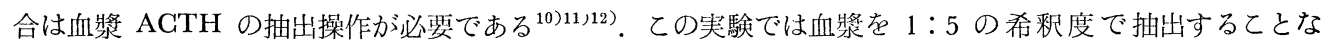

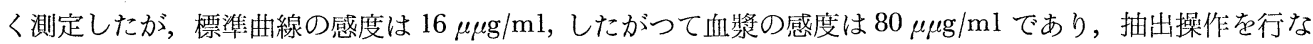
う必要が考えられた。この条件で測定した正常人の午前 9 時の值は 80 以下〜 $160 \mu \mu \mathrm{g} / \mathrm{ml}$ であり， dexamethasone 投与により全例とも $80 \mu \mu \mathrm{g} / \mathrm{ml}$ 以下となつた。副腎腺腫による Gushing 症候群では娭出不能であ り，過形成によるものは高值を示し，Addison 病の1例も著しく高值であつたが，乙れらの成績は従来の 報告と一致するものであつた ${ }^{122) 7) ~ 13) . ~}$

Cushing 症候群の副䡬腺腫と過形成との鑑別は尿 17-OHCS を指標とする場合，必ずしも判然としない 症例がある. Sparks らは metyrapone 投与による血中 AGTH の反応を bioassay により測定し，両者の 鑑別に用いている ${ }^{14)}$. 今回の実験でも過形成の 1 例では metyrapone 投与に対して尿 17-OHCS と血中 ACTH の増加がみられ，経舅的定位手術による下垂体高周波凝固術の 2 週後も同様であつた，腺腫による 2 例では尿 17-OHCS と血中 ACTH の反応は共に認められなかつた。 ての成續は metyrapone 亿対する ACTH の反応をみるととが，腺腫と過形成の鑑別あるいは過形成例に対する治療効果の判定に有用である ととを示唆するものと考光られた。

本論文の要旨は第43回日本内分泌学会総会扔よび第18回同西部部会総会にて発表した。acetylated wax D を提供いただいた九大胸部疾患研究所田中渥助教授, 御校閲いただいた勝木司馬之助教授, 咸部信彦教授に 樑謝する。

\section{文献}

1) Berson, S.A. and R.S. Yalow : J. Clin. Invest., $47: 2725$, (1968). $\quad$ 2) Orth, D.N., D.P. Island, W.E. Nicholson, K. Abe and J.P. Woodham : Radioisotopes in Medicine : in vitro studies, AEC Symposium Series, $13: 251$, (1968).

3) Tanaka, A., K. Tanaka, D. Hagimoto and K. Sugiyama: Int. Arch. Allergy, $32: 224$, (1967).

4) Greenwood, F.C., W.M. Hunter and J.S. Glover: Biochem. J., $89: 114$, (1963).

5) Yalow, R.S. and S.A. Berson : Nature, $312: 357$, (1966). 6) 西風 脩, 古屋悦子: 臨床病理, $15: 694$, (1967). 7) Rayyis, S.S. and J.E. Bethune : J. Clin. Endocr., $29: 1231$ ，(1969). 8) 松倉 茂：日本臨林, $27: 313 ，(1969)$ 9) Yalow, R.S., S.M. Glick, J. Roth and S.A. Berson : J. Clin. Endocr., $24: 1219$, (1964). 10) Landon, J. and F.C. Greenwood : Lancet, i : 273, (1968). 11$)$ Demura, H., C.D. West, G.A. Nugent, K. Nakagawa and F.H. Tyler : J. Clin. Endocr., $26: 1297$, (1966). 12) 五味二郎, 本間光夫, 市川陽一, 吉田幸一郎：日本内分泌誌，45:433，(1969)。 13) Besser, G.M. and J. Landon : Brit. Med. J., 4 : 552, (1968). $\quad$ 14) Sparks, L.L., R.P. Smilo, F.G. Pavlatos and P.H. Forsham : Metabolism, $18: 175$, (1969). 